Counsellia: Jurnal Bimbingan dan Konseling, 9 (1), | 201927 - 38

Copyright (C2019 Universitas PGRI Madiun

ISSN: 2088-3072 (Print) / 2477-5886 (Online)

Available online at: http://e-journal.unipma.ac.id/index.php/JBK

DOI: $10.25273 /$ counsellia.v9i1.3689

\title{
Analisis faktor konfirmatori sebagai prosedur evaluasi konstruk skala kematangan karir
}

\author{
Wahyu Widyatmoko ${ }^{1}$, Yulia Ayriza ${ }^{2}$, Riszal Purwandika ${ }^{3}$ \\ ${ }^{1}$ Pascasarjana Bimbingan dan Konseling, Universitas Negeri Yogyakarta, \\ Yogyakarta \\ wahyu_widyatmoko2016@student.uny.ac.id \\ ${ }^{2}$ Pascasarjana Bimbingan dan Konseling, Universitas Negeri Yogyakarta, \\ Yogyakarta \\ yulia_ayriza@uny.ac.id \\ ${ }^{3}$ Pascasarjana Bimbingan dan Konseling, Universitas Negeri Yogyakarta, \\ Yogyakarta \\ riszal_puwandika2016@student.uny.ac.id
}

\begin{abstract}
Abstrak
Artikel ini bermaksud mengevaluasi validitas dan reliabilitas skala kematangan karir. Skala kematangan karir dirancang untuk mengumpulkan data penelitian tentang tingkat kematangan karir pada siswa SMA. Skala tersebut terdiri dari 12 item pernyataan yang disesuaikan dengan konstruk kematangan karir, yakni: kepercayaan diri dalam karir (KDK), ketidakpastian pilihan karir (KPK), dan pengetahuan terhadap karir (PTK). Hasil analisis faktor konfirmatori mengindikasikan tiga konstruk model cocok ( $p$-vales $=0.50$; RMSEA=0.00; NFI= 0.99; CFI=1.00; GFI=0.99; AGFI=0.98). Selanjutnya, tujuh dari 12 item pernyataan skala kematangan karir terbukti valid (standardized loading berkisar antara 0.52 hingga 0.72 ; $t$-values berkisar antara 8.08 hingga 12.25) dan dua dari tiga konstruk skala kematangan karir reliabel $(\mathrm{KPK}=0.68$; $\mathrm{PTK}=0.70)$. Hal tersebut menunjukkan bahwa skala kematangan karir masih dapat digunakan sebagai instrumen pengumpul data dan alat asesmen.
\end{abstract}

Kata Kunci: kematangan karir, analisis faktor konfirmatori.

\begin{abstract}
The purpose of this article is to evaluate the validity and reliability of the career maturity scale. The career maturity scale is designed to collect research data on the level of career maturity in high school students. It is consists of 12 statement items tailored to the constructs of career maturity: career confidence, uncertainty of career choice, and career knowledge. The results of confirmatory factor analysis indicated that the three constructs of model was well fit ( $p$-vales $=0.50 ; R M S E A=0.00 ; N F I=0.99 ; C F I=1.00 ; G F I=0.99$; $A G F I=0.98)$. Further, seven out of 12 statement items on career maturity scale proved valid (standardized loading ranged from 0.52 to 0.72 ; $t$-values ranged from 8.08 to 12.25 ) and two of the three constructs of career maturity scale are reliable (KPK=0.68; $P T K=0.70$ ). This shows that the scale of career maturity can still be used as an instrument for data collection and assessment tools.
\end{abstract}

Keywords: career maturity, confirmatory factor analysis. 


\section{PENDAHULUAN}

Kemajuan zaman menuntut setiap individu memiliki kemampuan yang menunjang keberlangsungan hidupnya. Mereka dihadapkan dengan ketatnya persaingan dalam dunia kerja, sehingga membutuhkan persiapan yang matang sejak dini. Hal tersebut diperkuat dengan pendapat (Batubara, 2013) yang menyebutkan bahwa setiap individu dihadapkan dengan persiapan dan pengembangan karir yang komprehensif terkait kehidupan yang kompleks.

Persiapan karir dalam setting sekolah, terutama pada sekolah menengah atas (SMA) tidak dapat diabaikan. Siswa dihadapkan dengan dua kemungkinan, apakah mereka melanjutkan ke jenjang yang lebih tinggi atau melibatkan diri dalam dunia kerja setelah lulus sekolah. Sebagaimana (Davis, 2017) menyatakan gerakan perbaikan sekolah saat ini telah menekankan pada kesiapan karir dan perguruan tinggi siswa. Hal tersebut menunjukkan bahwa sekolah bertanggung jawab meyakinkan kesiapan siswa, apakah mereka melanjutkan pendidikan atau mengambil kesempatan berkarir setelah lulus sekolah (Davis, 2017; Mau, 2008)

Setiap individu memiliki ciri khas tersendiri baik dalam kesiapan maupun kematangan karirnya. Kematangan karir yang terjadi pada siswa SMA ditunjukkan dengan ketertarikan mereka terhadap suatu bidang karir tertentu. Beberapa contohnya seperti penguasaan terhadap suatu keterampilan, mencari informasi dan wawasan. Hal tersebut bertujuan agar mereka dapat menempati dan mampu menyesuaikan diri pada bidang karir tertentu di kemudian hari.

Donald E. Super (dalam Gysbers, Heppner, \& Johnston, 2014) menyatakan bahwa kematangan karir merupakan kesiapan untuk terlibat dalam tugas perkembangan yang sesuai tingkat usia seseorang. (Hartung, 2013) menambahkan kesiapan berupa sikap dan kognitif untuk membuat pilihan pendidikan dan pekerjaan. Kesiapan sikap adalah terlibat aktif dalam perencanaan dan mengeksplorasi sebuah pekerjaan di masa depan. Sementara itu, kesiapan kognitif adalah memiliki pengetahuan mengenai pekerjaan dan bagaimana membuat keputusan karir yang baik. Berdasarkan hal tersebut, siswa SMA hendaknya mampu membuat pilihan dan telah siap akan karir mereka nantinya.

Bidang bimbingan karir menjadi salah satu bagian integral program bimbingan dan konseling di sekolah. Bidang tersebut sebagai upaya guru BK dan konselor dalam memfasilitasi perkembangan karir siswa (konseli). Sofyan, Yusuf, dan (Daharmis, 2016) berpendapat bimbingan karir diperlukan untuk menguatkan serta meningkatkan aspirasi karir siswa SMA. Selain itu, intervensi karir langsung berfokus pada tugas identifikasi pilihan pekerjaan dan kejelasan karir siswa (Mau, 2008).

Pemberian bantuan berupa bimbingan maupun konseling bertujuan agar konseli dapat menyadari dan membuat keputusan mengenai arah tujuan karir mereka, apakah mereka melanjutkan ke perguruan tinggi atau memasuki dunia kerja setelah lulus sekolah (Davis, 2017; Neukrug, 2012). 
Bimbingan karir sebagai upaya guru BK mengatasi kesulitan konseli dalam memahami dirinya, mengenal dunia kerja, pengembangan diri, dan mengambil keputusan karir di masa depan (Hidayati, 2015; Lestari, 2017). Oleh karena itu, bimbingan dan konseling bidang karir menjadi penting guna memfasilitasi perkembangan karir konseli, sehingga kematangan karir mereka dapat terbentuk.

Asesmen terhadap kematangan karir siswa merupakan bagian dari aktivitas layanan bimbingan dan konseling. Berbagai alat atau instrumen asesmen karir telah banyak dikembangkan dan digunakan oleh para peneliti. Di samping itu, instrumen-instrumen tersebut tentu sangat berguna bagi guru BK dan konselor dalam melakukan asesmen layanan karir siswa. Sebagaimana Harrington dan Long (2013) menyatakan bahwa inventori minat dan asesmen karir terus menerus digunakan untuk mendukung para praktisi dalam mengungkapkan keterampilan, motivasi, nilai-nilai, dan faktorfaktor pribadi individu (konseli) serta membantu konseli menentukan dan membangun karir mereka.

Career Maturity Inventory (CMI; Crites, 1965). Inventori tersebut bertujuan mengukur tingkat perkembangan karir siswa mengenai sikap dan kompetensi mereka. Selanjutnya, hasil revisi terhadap inventori tersebut menunjukkan CMI Form C menyediakan skor total untuk mengukur kesiapan pilihan karir, skor tiga skala untuk mengukur tiga dimensi (kemampuan beradaptasi karir, rasa ingin tahu, dan kepercayaan diri) dan skor yang mengukur gaya relasi dalam membentuk pilihan pekerjaan (Savickas \& Porfeli, 2011).

Student Career Construction Inventory (SCCI; Savickas, Porfeli, Hilton, \& Savickas, 2018). Inventori tersebut bertujuan mengukur respons penyesuaian diri siswa, yang terdiri dari gagasan dan perilaku kejuruan dalam membentuk pilihan karir mereka. Adapun empat dimensi yang diukur oleh SCCI, antara lain: kristalisasi konsep diri kejuruan, eksplorasi informasi pekerjaan, komitmen terhadap keputusan pilihan kerja, dan persiapan dalam menerapkan pilihan tersebut. Selanjutnya, hasil analisis awal terhadap SCCI menunjukkan tidak ada perbedaan signifikan terhadap gender responden SMA, perguruan tinggi, serta pascasarjana.

Childhood Career Development Scale (CCDS; Stead \& Schultheiss, 2003). Skala tersebut dirancang untuk mengukur perkembangan karir siswa sekolah dasar. Lebih lanjut, konstruk dasar CCDS mengacu pada teori perkembangan karir Super. Skala tersebut mengukur sembilan dimensi perkembangan, antara lain: keingintahuan, eksplorasi, informasi, tokoh-tokoh penting, minat locus of control, perspektif waktu, konsep diri, dan perencanaan. Selanjutnya, hasil pengujian instrumen terhadap siswa sekolah dasar di Afrika Selatan menunjukkan bahwa CCDS tetap valid dan reliabel di wilayah tersebut (Stead \& Schultheiss, 2010). Di sisi lain, CCDS juga dapat digunakan untuk mengukur perkembangan karir siswa SMP (Ferrari, Nota, Schultheiss, Stead, \& Davis, 2017).

Career Future Inventory (CFI; Rottinghaus, Day, \& Borgen, 2005). 
CFI mengukur tiga dimensi dari manajemen diri tentang karir: adaptasi karir, optimisme karir, dan pengetahuan tentang pasar kerja. Selanjutnya, hasil revisi CFI berupa Career Future Inventory-Revised (CFI-R) menujukkan inventori tersebut dapat membantu konselor dalam memahami sikap konseli terhadap berbagai perubahan karir dan meningkatkan efektifitas konseling karir. (Rottinghaus, Buelow, Matyja, \& Schneider, 2012). Park et al. (2018) menambahkan CFI-R memiliki tingkat adaptasi karir yang sama, baik mengukur sampel klinis maupun non klinis. Sementara, McIlveen, Burton, dan Beccaria (2013) mengungkapkan CFI bentuk ringkas (CFI-9) memiliki konsistensi internal yang dapat diterima dan berkorelasi dalam mengukur kepuasan utama akademik, kepuasan pilihan karir, dan efikasi diri umum.

Career Decision-Making Profile (CDMP; Gati, Landman, Davidovitch, Asulin-Peretz, \& Gadassi, 2010). Kuesioner tersebut dirancang guna menguji model multidimensi yang menggambarkan perbedaan individu dalam mengambil keputusan karir. Adapun 11 dimensi yang diukur oleh CDMP, adalah: pengumpulan informasi, memproses informasi, locus of control, berusaha, prokrastinasi, kecepatan mengambil keputusan akhir, mengonsultasikan dengan orang lain, ketergantungan dengan orang lain, keinginan untuk menyenangkan orang lain, aspirasi mengenai pekerjaan yang ideal, dan kesediaan untuk berkompromi.

Career Factors Inventory (CFI; Chartrand, Robbins, Morrill, \&
Boggs, 1990). Inventori tersebut merupakan instrumen yang mengukur faktor multidimensi terjadinya keragu-raguan dalam karir. Adapun yang diukur dengan CFI meliputi faktor akan kebutuhan informasi (informasi karir dan pengetahuan diri) dan faktor emosional-personal (kecemasan pilihan karir dan keragu-raguan secara umum). Hasil telaah CFI versi Itali menunjukkan instrumen tersebut valid dan reliabel untuk evaluasi dimensi keragu-raguan karir (Presti, Pace, Cascio, \& Capuano, 2014).

Career Decision-Making Difficulties Questionnaire (CDDQ; Gati, Krausz, \& Osipow, 1996). Kuesioner tersebut berbasis pada taksonomi teoretis kesulitan dalam membuat keputusan karir. Teori tersebut mengacu pada teori keputusan yang telah dikembangkan sebelumnya. Selanjutnya, hasil pengujian terhadap CDDQ versi Cina menunjukkan struktur empiris 10 skala CDDQ selaras dengan model teoretisnya, sehinga kuesioner tersebut dapat digunakan untuk tujuan konseling dan penelitian (Tien, 2001). Hasil pengembangan CDDQ lainnya yakni versi Kroasia memiliki bukti reliabilitas yang memadai, baik pada tingkat sub skala, kelompok kesulitan utama, dan skor total (Babarović \& Šverko, 2018).

Instrumen kematangan karir siswa yang terstandar masih tetap dibutuhkan. Skala kematangan karir merupakan instrumen yang telah disusun oleh penulis. Skala tersebut mengadaptasi model konstruk kematangan karir penelitian terdahulu (Dybwad, 2008). Model yang telah dikembangkan oleh 
Dybwad mengukur lima dimensi kematangan karir, yakni: sikap, dukungan, kepercayaan terhadap kemampuan diri (self-assurance), pilihan yang tidak menentu, dan pengetahuan dunia kerja.

Analisis faktor sebagai metode statistik digunakan untuk membuktikan validitas dan reliabilitas instrumen skala. Analisis faktor memainkan peran penting dalam memvalidasi instrumen (Dimitrov, 2012). Azwar (2011) menambahkan analisis faktor adalah prosedur statistik yang biasa digunakan untuk mengembangkan dan menganalisis hubungan antar variabel dari suatu instrumen. Di samping itu, analisis faktor telah banyak digunakan secara luas dalam penelitian pengembangan skala dan analisis tersebut merupakan prosedur statistik yang fleksibel serta digunakan oleh para peneliti dalam berbagai cara (Kahn, 2006; Mvududu \& Sink, 2013).

Artikel ini bermaksud mengevaluasi validitas dan reliabilitas instrumen skala kematangan karir yang telah disusun oleh penulis. Evaluasi menggunakan prosedur statistik analisis faktor konfirmatori atau Confirmatory Factor Analysis (CFA). Hal tersebut dikarenakan skala yang telah disusun oleh penulis memodifikasi model konstruk teoretik kematangan karir penelitian terdahulu (Dybwad, 2008). Adapun konstruk teori yang telah dimodifikasi sebagai berikut: kepercayaan diri dalam karir, ketidakpastian terhadap pilihan karir, dan pengetahuan terhadap karir. Skala kematangan karir yang telah disusun dapat membantu praktisi (guru BK dan konselor) dan peneliti lain dalam mengumpulkan data mengenai tingkat kematangan karir siswa.

\section{METODE PENELITIAN}

Sumber data dalam penelitian ini adalah siswa SMA di Kabupaten Pacitan, Provinsi Jawa Timur yang berjumlah 3.952 anak. Pengambilan sampel penelitian menggunakan proportionate stratified random sampling, karena anggota populasi tidak homogen dan berstrata secara proporsional (Sugiyono, 2017). Oleh karena itu, sampel dalam penelitian ini sebesar 354 siswa.

Teknik pengumpulan data dalam penelitian ini berupa self-report yang berbentuk skala kematangan karir. Skala kematangan karir yang disusun oleh penulis memodifikasi skala kematangan karir yang disusun oleh Dybwad (2008). Adapun skala yang telah dimodifikasi mengukur aspek kepercayaan diri dalam karir, aspek ketidakpastian pilihan karir, dan aspek pengetahuan terhadap karir.

Pengumpulan data dilakukan oleh peneliti (penulis ketiga) di empat SMA di Kabupaten Pacitan, Provinsi Jawa Timur. Pelaksanaan pengumpulan data telah pada bulan Agustus hingga September 2018 dan memperoleh izin dari Dinas Pendidikan setempat serta pihak sekolah. Selanjutnya siswa secara sukarela mengisi instrumen yang dibagikan oleh peneliti.

Data yang telah terkumpul dianalisis menggunakan analisis faktor konfirmatori dengan bantuan program Lisrel 8.80. Berdasarkan analisis tersebut akan menampilkan nilai-nilai model konstruk, nilai standardized loading (loading indikator) dan nilai t-values. Nilai- 
nilai tersebut digunakan untuk menentukan kriteria kecocokan model konstruk dan tingkat validitas. Sementara itu untuk menentukan dan mengevaluasi reliabilitas instrumen, penelitian ini menggunakan formula construct reliability (CR), sebagai berikut (Ghozali \& Fuad, 2014):

$$
\mathrm{CR}=\frac{(\Sigma \lambda)^{2}}{\left[\left(\Sigma^{\lambda}\right)^{2}+\Sigma(\theta)\right]}
$$

$$
\begin{aligned}
& \lambda=\begin{array}{l}
\text { Loading indikator } \\
\text { (standardized loading) }
\end{array} \\
& \theta=\underset{\text { Error variance indikator }}{\left.\lambda^{2}\right)}
\end{aligned}
$$

\section{HASIL DAN PEMBAHASAN}

Berdasarkan proportionate stratified random sampling, rincian populasi dan sampel dalam penelitian ini dapat dilihat pada tabel 1 .

Di mana:

$\mathrm{CR}=$ Construct reliability

Tabel 1. Populasi dan Sampel Penelitian

\begin{tabular}{lcc}
\hline \multicolumn{1}{c}{ Kelas } & Populasi & Sampel \\
\hline X IPS & $542(14 \%)$ & $49(14 \%)$ \\
\hline X IPA & $730(18 \%)$ & $65(18 \%)$ \\
\hline XI IPS & $563(14 \%)$ & $51(14 \%)$ \\
\hline XI IPA & $749(19 \%)$ & $67(19 \%)$ \\
\hline XII IPS & $696(18 \%)$ & $62(18 \%)$ \\
\hline XII IPA & $672(17 \%)$ & $60(17 \%)$ \\
\hline Total & $\mathbf{3 . 9 5 2 ( 1 0 0 \% )}$ & $\mathbf{3 5 4 ( 1 0 0 \% )}$ \\
\hline
\end{tabular}

Skala kematangan karir yang telah disusun oleh penulis mengukur tiga aspek kematangan karir. Jumlah seluruh item skala kematangan karir adalah 12 pernyataan. Adapun rincian skala kematangan karir, sebagai berikut: (1) Aspek kepercayaan diri dalam karir (KDK) diukur dengan empat item pernyataan (item 1 , item 2 , item 3 , item 4); (2) Aspek ketidakpastian pilihan karir (KPK) diukur dengan empat item pernyataan (item 5 , item 6, item 7, item 8); dan aspek pengetahuan terhadap karir (PTK) diukur dengan empat item pernyataan (item 9 , item 10 , item 11 , item 12). Skala kematangan karir dapat dilihat pada lampiran 1 .

Setiap item pernyataan disediakan empat respons jawaban yang berbasis skala Likert (sangat sesuai, sesuai, tidak sesuai, dan sangat tidak sesuai). Selanjutnya, penskoran jawaban untuk setiap item dapat dilihat pada tabel 2.

Berdasarkan validasi dua orang ahli (expert-judgment) bidang bimbingan dan konseling menyatakan bahwa 12 item pernyataan skala kematangan karir sesuai untuk mengukur kematangan karir pada siswa SMA. Setelah instrumen disebar kepada siswa, diperoleh data kuantitatif. Data tersebut dianalisis menggunakan analisis faktor konfirmatori guna menentukan validitas dan reliabilitas skala kematangan karir yang telah disusun. 
Tabel 2. Penskoran Jawaban Setiap Item

\begin{tabular}{lcccc}
\hline \multirow{1}{*}{ Item } & \multicolumn{4}{c}{ Skor Jawaban } \\
\cline { 2 - 5 } & SS & S & TS & STS \\
\hline Item 1 & 4 & 3 & 2 & 1 \\
\hline Item 2 & 4 & 3 & 2 & 1 \\
\hline Item 3 & 1 & 2 & 3 & 4 \\
\hline Item 4 & 1 & 2 & 3 & 4 \\
\hline Item 5 & 1 & 2 & 3 & 4 \\
\hline Item 6 & 1 & 2 & 3 & 4 \\
\hline Item 7 & 1 & 2 & 3 & 4 \\
\hline Item 8 & 1 & 2 & 3 & 4 \\
\hline Item 9 & 1 & 2 & 3 & 4 \\
\hline Item 10 & 1 & 2 & 3 & 4 \\
\hline Item 11 & 1 & 2 & 3 & 4 \\
\hline Item 12 & 4 & 3 & 2 & 1 \\
\hline
\end{tabular}

Hasil analisis faktor konfirmatori skala kematangan karir menunjukkan bahwa nilai standardized loading lima item pernyataan skala kematangan karir di bawah 0.50, yakni: item 1 (0.15), item $2(0.22)$, item $6(0.35)$, item 9 (0.43), dan item 12 (0.24). Instrumen dikatakan valid apabila nilai standardized loading lebih besar dari 0.50 dan $t$-values lebih besar dari pada 1.96 (Ghozali \& Fuad, 2014; Hendryadi \& Suryani, 2014; Jr., Black, Babin, \& E. Anderson, 2014; Retnawati, 2016). Berdasarkan hal tersebut, dari 12 item pernyataan yang terdapat dalam skala kematangan karir, lima item diantaranya memiliki nilai di bawah 0.50 .

Eliminasi dilakukan terhadap lima item yang di bawah 0.50, sehingga tujuh item yang tersisa dianalisis ulang. Hasil analisis ulang menunjukkan model konstruk skala termasuk kriteria baik (good fit). Hal tersebut diketahui berdasarkan pembandingan antara kriteria model fit dengan hasil index model konstruk skala kematangan karir yang ditampilkan dalam analisis faktor konfirmatori. Adapun kriteria model fit dan hasil analisis model konstruk kematangan karir dapat dilihat pada tabel 3.

Tabel 3. Hasil Kecocokan Model Pengukuran

Skala Kematangan Karir

\begin{tabular}{lccc}
\hline \multicolumn{1}{c}{ Indeks Model } & Kriteria Kecocokan & Hasil & Keterangan \\
\hline$p$-values & $\geq 0.05$ & 0.50 & Good fit \\
\hline RMSEA & $\begin{array}{c}<0.05: \text { good fit } ;<0.08: \\
\text { reasonable fit }\end{array}$ & 0.00 & Good fit \\
\hline NFI & $>0.90$ & 0.99 & Good fit \\
\hline CFI & $>0.90$ & 1.00 & Good fit \\
\hline GFI & $>0.90$ & 0.99 & Good fit \\
\hline AGFI & $>0.90$ & 0.98 & Good fit \\
\hline
\end{tabular}


Hasil analisis terhadap tujuh item pernyataan skala kematangan karir terbukti valid. Hal tersebut diketahui dari nilai standardized loading dan $t$-values dari skala kematangan karir. Nilai standardized loading setiap item di atas 0.50, yakni: item 3 (0.52), item 4 (0.76), item 5 (0.59), item 7 (0.67), item 8
(0.69), item 10 (0.72), dan item 11 (0.76). Sementara, nilai $t$-values setiap item di atas 1.96, yakni: item 3 (8.08), item 4 (10.06), item 5 (10.39), item 7 (11.94), item 8 (12.25), item 10 (11.00), dan item 11 (11.44). Diagram jalur standardized loading dari tujuh item tersebut dapat dilihat pada gambar 1 .

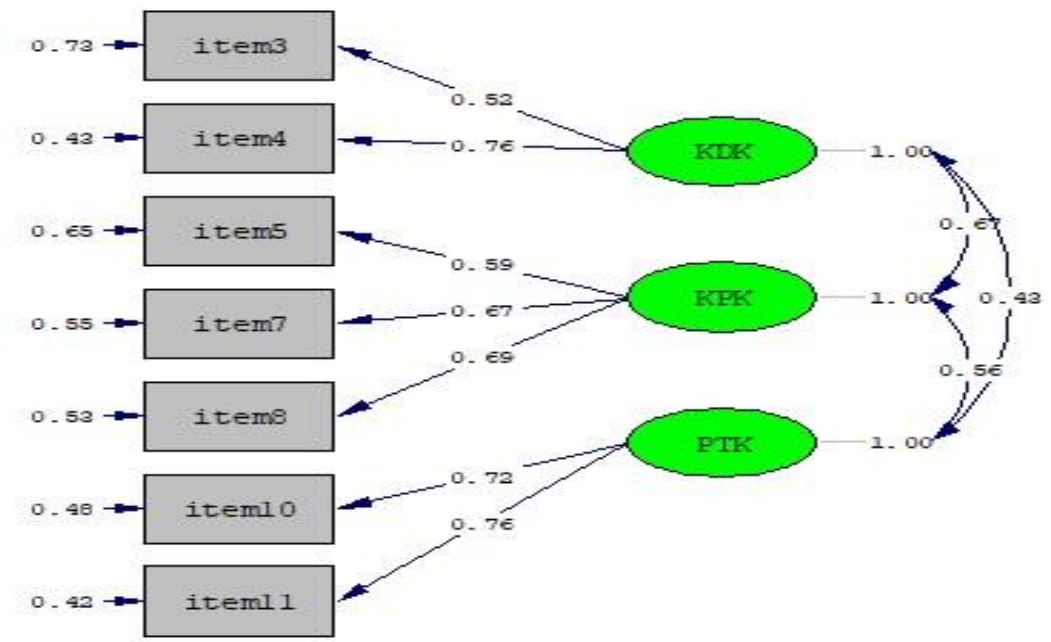

Gambar 1. Hasil Standardized Loading CFA dengan Tujuh Item

Analisis faktor konfirmatori juga menelaah reliabilitas suatu item instrumen melalui nilai squared multiple correlations $\left(\mathrm{R}^{2}\right)$. Hasil analisis $\mathrm{R}^{2}$ mengindikasikan seberapa besar proporsi varians item yang dijelaskan oleh variabel laten (Ghozali \& Fuad, 2014). Berdasarkan hal tersebut, hasil analisis squared multiple correlations terhadap aspekaspek skala kematangan karir dapat dilihat pada tabel 4 .

Tabel 4. Hasil Analisis Skala Kematangan Karir

\begin{tabular}{lcc}
\hline \multicolumn{1}{c}{ Aspek } & Item & $\mathbf{R}^{2}$ \\
\hline Kepercayaan diri & Item 3 & 0.27 \\
\cline { 2 - 3 } dalam karir (KDK) & Item 4 & 0.57 \\
\hline \multirow{2}{*}{$\begin{array}{lcc}\text { Ketidakpastian } \\
\text { pilihan karir (KPK) }\end{array}$} & Item 5 & 0,35 \\
\cline { 2 - 3 } & Item 7 & 0.45 \\
\cline { 2 - 3 } $\begin{array}{lcc}\text { Pengetahuan } \\
\text { terhadap karir (PTK) }\end{array}$ & Item 10 & 0.52 \\
\cline { 2 - 3 } & Item 11 & 0.52 \\
\hline
\end{tabular}

Dalam tabel 4 menunjukkan item 11 memiliki nilai $\mathrm{R}^{2}$ tertinggi (0.58). Nilai tersebut dimaknai bahwa variabel laten KDK berkontribusi terhadap varians item
11 sebesar 58\%. Sementara, item 3 kurang reliabel dari variabel laten KDK karena memiliki nilai $\mathrm{R}^{2}$ terkecil (0.27). 
Berdasarkan penghitungan construct reliability (CR), hasil analisis reliabilitas skala kematangan karir diketahui bahwa dua variabel laten memiliki nilai $\mathrm{CR}$ lebih besar dari 0.6. Variabel tersebut diantaranya ketidakpastian pilihan karir (0.68) dan pengetahuan terhadap karir (0.70). Sementera itu, variabel laten kepercayaan diri dalam karir miliki CR yang rendah (0.58). CR yang diharapkan semestinya lebih besar dari 0.6 (Hair et al., 2014).

Model konstruk skala kematangan karir secara keseluruhan termasuk kriteria yang baik (good fit). Di samping itu, hasil evaluasi berdasarkan analisis faktor konfirmatori menunjukan secara konstruk item-item pernyataan skala kematangan karir terbukti valid. Sementara, reliabilitas konstruk skala kematangan karir menunjukkan dua aspeknya sesuai dengan yang diharapkan. Adapun kedua aspek tersebut, yakni: ketidakpastian pilihan karir dan pengetahuan terhadap karir.

Pelaksanaan asesmen karir menyertakan berbagai bukti tentang pengelolaan karir individu (Kidd, 2006). Kidd melanjutkan bahwa hasil dari asesmen dipandang sebagai salah satu elemen membantu proses konseling karir. Skala kematangan karir dirancang sebagai salah satu alat asesmen yang mempermudahkan pengumpulan data. Instrumen tersebut dapat dimanfaatkan oleh praktisi (guru BK, konselor) dan peneliti lain, guna mengukur tingkat kematangan karir siswa SMA. Di samping itu, beberapa kriteria dalam memilih instrumen tertentu, diantaranya adalah validitas dan reliablitas (Gysbers, et al., 2014). Berdasarkah hal tersebut, bukti validitas dan reliabilitas skala kematangan karir perlu diketahui.

Instrumen yang baik dan terstandar adalah instrumen harus memenuhi kriteria valid serta reliabel. Sebagaimana Sugiyono (2017) menyatakan valid dan reliabelnya instrumen, diharapkan hasil penelitian juga menjadi valid dan reliabel. Selain itu, instrumen harus memiliki bukti validitas dan reliabilitas dalam mengukur suatu objek (Widoyoko, 2017). Skala kematangan karir berdasarkan evaluasi model pengukuran termasuk kategori baik (good fit). Skala tersebut memiliki 12 item pernyataan dengan 7 item yang mendukung bukti validitas dan reliabilitas berdasarkan analisis faktor konfirmatori. Di mana setiap itemnya yang tersisa masih dapat mengukur konstruk teori kematangan karir. Hal tersebut menunjukan bahwa skala kematangan karir yang telah dirancang masih dapat digunakan untuk instrumen pengumpul data maupun sebagai alat asesmen.

\section{SIMPULAN}

Skala kematangan karir telah memenuhi kriteria model yang baik ( $p$-values, RMSEA, NFI, CFI, GFI, dan AGFI). Selanjutnya, jumlah item skala kematangan karir adalah 12 pernyataan. Namun, hanya tujuh item yang terbukti valid dan reliabel secara konstruk, yakni: item 3, item 4 , item 5 , item 7 , item 8 , item 10 , dan item 11. Berdasarkan hal tersebut, skala kematangan karir masih dapat digunakan sebagai instrumen pengumpul data maupun sebagai alat 
asesmen. Selain model pengukurannya termasuk kriteria baik (good fit), tujuh dari 12 item pernyataan telah mewakili setiap konstruk teori kematangan karir (kepercayaan diri dalam karir, ketidakpastian pilihan karir, dan pengetahuan terhadap karir).

\section{DAFTAR PUSTAKA}

Azwar, S. (2011). Reliabilitas Dan Validitas. Yogyakarta: Pustaka Pelajar. Yogyakarta: Pustaka Pelajar. https://doi.org/10.22146/bpsi.13 381

Babarović, T., \& Šverko, I. (2018). The Validity of Career Decision-Making Difficulties Questionnaire in Croatia. Journal of Career Assessment, 20(10), $1-17$. https://doi.org/10.1177/106907 2717748960

Batubara, J. (2013). Perkembangan dan Pemilihan Karier Menurut Ginzberg dan Implikasinya terhadap Bimbingan dan Konseling. Jurnal Konseling Dan Pendidikan, 1, 43-47.

Chartrand, J. M., Robbins, S. B., Morrill, W. H., \& Boggs, K. (1990). Development and validation of the Career Factors Inventory. Journal of Counseling Psychology, 37, 491-501.

https://doi.org/https://psycnet.a pa.org/doi/10.1037/0022-

0167.37.4.491

Crites, J. O. (1965). Measurement of vocational maturity in adolescence: I. Attitude test of the Vocational Development Inventory. Psychological
Monographs: General and Applied, 79, 1-34. https://doi.org/https://psycnet.ap a.org/doi/10.1037/h0093875

Davis, T. E. (2017). School Counseling. In D. Capuzzi \& D. R. Gross (Eds.), Introduction to the Counseling Profession: Seventh Edition (seventh, pp. 410-432). New York: Routledge.

https://doi.org/10.4324/9781315 537061

Dimitrov, D. M. (2012). Statistical Methods for Validation of Assessment Scale Data in Counseling and Related Fields. Alexandria: American Counseling Association.

Dybwad, T. (2008). The structural validity of daidalos: A measure of career maturity. Scandinavian Journal of Educational Research, 52, 135-152. https://doi.org/10.1080/0031383 0801915762

Ferrari, L., Nota, L., Schultheiss, D. E., Stead, G. B., \& Davis, B. L. (2017). Validation of the Childhood Career Development Scale Among Italian Middle School Students. Journal of Career Assessment, 20(10), 117.

https://doi.org/10.1177/1069072 717727483

Gati, I., Krausz, M., \& Osipow, S. (1996). A Taxonomy of Difficulties in Career Decision Making. Journal of Counseling Psychology, 43, 510-526. https://doi.org/10.1037/00220167.43.4.510

Gati, I., Landman, S., Davidovitch, S., Asulin-Peretz, L., \& Gadassi, R. (2010). From career decision- 
making styles to career decision-making profiles: A multidimensional approach. Journal of Vocational Behavior, 76(2), 277-291. https://doi.org/https://doi.org/10 .1016/j.jvb.2009.11.001

Ghozali, I., \& Fuad. (2014). Structural Equation Modeling: Teori, Konsep, dan Aplikasi dengan Program Lisrel 9.10. Semarang: Universitas Diponegoro.

Gysbers, N. C., Heppner, M. J., \& Johnston, J. A. (2014). CAREER COUNSELING: Holism, Diversity, and Strengths (4th ed.). Alexandria: American Counseling Association.

Harrington, T., \& Long, J. (2013). The History of Interest Inventories and Career Assessments in Career Counseling. The Career Development Quarterly, 61(1), 83-92.

https://doi.org/10.1002/j.21610045.2013.00039.x

Hartung, P. J. (2013). The LifeSpan, Life-Space Theory of Careers. In S. D. Brown \& R. W. Lent (Eds.), Career development and counseling: putting theory and research to work (Second Edi, pp. 83-114). Hoboken: John Wiley \& Sons, Inc.

Hendryadi, \& Suryani. (2014). Structural Equation Modeling dengan Lisrel 8.80: Pedoman untuk Pemula. Yogyakarta: Kaukaba Diapantara.

Hidayati, R. (2015). LAYANAN INFORMASI MEMBANTU
DIDIK MENINGKATKAN

PEMAHAMAN

JURNAL GUSJIGANG, 1 .

Jr., J. F. H., Black, W. C., Babin, B. J., \& E. Anderson, R. (2014). Multivariate Data Analysis (7th ed.). Harlow: Pearson Education Limited.

Kahn, J. H. (2006). Factor Analysis in Counseling Psychology Research, Training, and Practice: Principles, Advances, and Applications. The Counseling Psychologist. https://doi.org/10.1177/0011000 006286347

Kidd, J. M. (2006). Understanding Career Counselling Theory, Research and Practice. London: SAGE Publications Ltd.

Lestari, I. (2017). MENINGKATKAN

KEMATANGAN KARIR

REMAJA MELALUI BIMBINGAN KARIR BERBASIS LIFE SKILLS. JURNAL KONSELING GUSJIGANG, 3(1), 17-27.

Mau, W.-C. J. (2008). Career Development Interventions in Schools. In H. L. K. Coleman \& C. Yeh (Eds.), Handbook of School Counseling (pp. 497516). New York: Taylor \& Francis Group.

Mcllveen, P., Burton, L. J., \& Beccaria, G. (2013). A Short Form of the Career Futures Inventory. Journal of Career Assessment, 21(1), 127-138. https://doi.org/10.1177/1069072 712450493

Mvududu, N. H., \& Sink, C. A. (2013). Factor Analysis in 
Counseling Research and Practice. Counseling Outcome Research and Evaluation. https://doi.org/10.1177/215013 7813494766

Neukrug, E. (2012). The World of the Counselor An Introduction to the Counseling Profession (4th ed.). Belmont: Brooks/Cole.

Park, C. J., Rottinghaus, P. J., Wang, Z., Zhang, T., Falk, N. A., \& Ko, S.-J. (2018). Measurement Invariance of the Career Futures Inventory-Revised Across General and Client Samples. Journal of Career Assessment, 20(10), 1-15. https://doi.org/10.1177/106907 2718816514

Presti, A. Lo, Pace, F., Cascio, V. Lo, \& Capuano, M. (2014). The Italian Version of the Career Factors Inventory. Journal of Career Assessment, 25(2), 326337.

https://doi.org/10.1177/106907 2714565857

Retnawati, H. (2016). Analisis Kuantitatif Instrumen Penelitian (Panduan Peneliti, Mahasiswa, dan Psikometri). Yogyakarta: Parama Publishing.

Rottinghaus, P. J., Buelow, K. L., Matyja, A., \& Schneider, M. R. (2012). The Career Futures Inventory-Revised: Measuring Dimensions of Career Adaptability. Journal of Career Assessment, 20(2), 123-139. https://doi.org/10.1177/106907 2711420849

Rottinghaus, P. J., Day, S. X., \& Borgen, F. H. (2005). The Career Futures Inventory: A
Measure of Career-Related Adaptability and Optimism. Journal of Career Assessment, 13(1), 3-24. https://doi.org/10.1177/1069072 704270271

Savickas, M. L., \& Porfeli, E. J. (2011). Revision of the Career Maturity Inventory: The Adaptability Form. Journal of Career Assessment, 19(4), 355374.

https://doi.org/10.1177/1069072 711409342

Savickas, M. L., Porfeli, E. J., Hilton, T. L., \& Savickas, S. (2018). The Student Career Construction Inventory. Journal of Vocational Behavior, 106, 138-152.

https://doi.org/https://doi.org/10. 1016/j.jvb.2018.01.009

Sofyan, A., Yusuf, A. M., \& Daharmis. (2016). Tingkat Aspirasi Karir Siswa di Tinjau dari Jenis Kelamin, Jurusan dan Daerah Tempat Tinggal. Jurnal Konseling Dan Pendidikan.

Stead, G. B., \& Schultheiss, D. E. P. (2003). Construction and Psychometric Properties of the Childhood Career Development Scale. South African Journal of Psychology, 33(4), 227-235. https://doi.org/10.1177/0081246 30303300405

Stead, G. B., \& Schultheiss, D. E. P. (2010). Validity of Childhood Career Development Scale Scores in South Africa. International Journal for Educational and Vocational Guidance2, 10, 73-88. https://doi.org/http://scihub.tw/10.1007/s10775-0109175-y 
Sugiyono. (2017). Statistika Untuk Penelitian. Bandung: Alfabeta.

Tien, H.-L. S. (2001). Career Decision-Making Difficulties Perceived by College Students in Taiwan. Bulletin of Educational Psychology and Counseling, 33.

Vieira, A. L. (2011). Interactive LISREL in Practice Getting Started with a SIMPLIS Approach. New York: Springer.

Widoyoko, E. P. (2017). Teknik Penyusunan Instrumen Penelitian. Yogyakarta: Pustaka Pelajar. 